\title{
Comparative-typological Analysis of Kazakh Historical Songs
}

\author{
Zhanar Baltabekovna Akhmetzhanova \\ Klara Tursynkhanovna Kabataeva \\ Muslima Sharipovna Toizhigitova
}

Karaganda Economic University of Kazpotrebsoyuz, 100009, Academicheskaya street 9, Karaganda city The Republic of Kazakhstan; Email: zhanar-ahmetzhan@mail.ru

Doi:10.5901/mjss.2015.v6n5s2p240

\begin{abstract}
Historical songs are an integral part of the fund of Kazakh folk songs. There were objective and subjective reasons that to this day they have not been the object of special scientific monographic study. The main purpose of the work is an attempt to create a thematic classification of Kazakh historical songs, definitions of genre features of historical songs, their poetic identity and place in the oral folk art. There is an idea of freethinking, independence and protection of native land, a reflection of people's dreams at the heart of historical songs. Hence appears the difference of historical songs from historical epics. If in historical epics heroism and courage are widely praised, the image of the hero is described; in historical songs the sadness and sorrow of all people are reflected.
\end{abstract}

Keywords: historical songs, traditional features, comparative typology, image, motif, plot, artistic means.

\section{Introduction}

A specific feature of historical songs is their similarity in content and form with poetic samples of other related peoples. It follows from this that in their study one must diachronically penetrate into historical events that served as the reason for the origin of the work. It is known that many of the events led to profound changes in a certain historical period, respectively leave an imprint on the culture and literature of nation. At the same time, it is possible to refer to statements of Sh. Ybrayev, who wrote: "So, the main feature of the typology is its historicity. Historical typology is a process in motion and continuous change for us. Historical typology explores folklore in diachronic position extended on the mirror of history in all its grandeur and beauty "[19]. That in itself appears the need to study historical songs wider by nationwide scale. In this connection, one can refer to the following, in our view, convincing statements of B.N. Putilov: "Typology, he writes, is as a certain pattern, we can say literally permeates folklore at all levels occurring naturally systematically and internally due to historical and typological relations and it characterizes folklore on the whole as a specific type of creativity and as a set of real-world results of this creativity and its individual elements. We have the right to speak, for example, about the typology of images, motifs, themes, artistic means, the typology of genres and genre varieties, the typology of folklore processes, relations of folklore to reality [for example, the typology of folk historicism] wider - the typology of folk consciousness "[11]. It is necessary to specify what should be done in achieving this purpose, which directions and courses must be taken. It is clear that the judgments of cited person and other authors do not give a full answer to all the conditions of typological studies, but together indicate historicism as one of the important if not the main requirements to researchers in problems of historical songs. The main thing is that historical songs should be distinguished in national frameworks, they were created on the basis of different situations to reveal reasons of their appearance. Taking into account these circumstances, we decided to study in the direction typological relation. Cultural and literary connections, relations and interpenetration of peoples and nations, their territorial and spiritual closeness, if not affinity but similarity of historical conditions of life, and much more cause folklore, as a phenomenon of a single and whole in the broadest sense, and personality traits of the folklore of each individual people. This is the phenomenon of folklore as a manifestation of social consciousness.

\section{Methods}

Almost all researchers have noted before the distinguishing feature of historical songs that they reflect the de facto of 
occurred event, the leitmotif of the work is a mood, joy and sorrow, the mental state of the author-poet. Similar judgments we find in studies A.Baitursynov, H. Dosmuhameduly, M Auezov, S.Seifullin, A.Margulan, A. Konyratbaev, R. Berdybaev, S. Kaskabasov, E. Tursynov, B.S. Rakhymov and others. All of the above research scientists agree about the birth of historical songs in the distant past, the various stages of the birth and development, thereby reflecting the historical reality of a particular historical period.

At one time, researchers F.E. Korsch, A.N. Bernstam, P.M. Melioransky, I.V. Stebleva and others reviewing ancient poetic monument of the Turkic peoples of the East "Orkhon-Yenisey" texts indicate that some of their samples repeat contents of proverbs and sayings of the peoples of Central Asia and Kazakhstan. So, I.V. Stebleva points directly to the "common language in the structure of the Orkhon-Yenisey Turks with the Kazakh language. So, she writes, we can assume that ancient Turkic songs and modern Kazakh versification were mutually close, akin even in those ancient times, when there was no full-blooded written literature" [16]. Kazakh scientist M.O. Auezov developing this idea, wrote: "What are the Orkhon inscriptions? Until now, researchers pay attention to them, as artefact of the language history. At that time they were the oldest examples of special folklore. These texts embodied small yet very capacious plot of epic legends" [1]. Academician S. Kaskabasov writes: "Historical songs are born in different periods of the history of society, in this respect; they are examples of operational genre. This suggests that historical songs are generation of ancient times. They include, general Turkic heritage of ancient literature: poems about Bilge Haganah, Kultegin, Tonyuquq, etc. found in the Orkhon-Yenisey valley. And the later songs are dedicated to the individual events of the Great Patriotic War" [8].

Thus, based on the cyclical nature of history the scientist points to the law of transformation of historical songs into epic narratives. This idea complements R. Berdybay who sees many similarities in historical songs and rich folklore. As the proof he gives many examples in the form of songs from the Orkhon-Yenisey texts, historical songs of Karluk, OguzKipchak associations, Karakhanids, Jochi Ulus, Altyn Orda and Ak Orda, the Kazakh Khanate times, which reflect the specific historical events. At the same time, R. Berdybai offers to consider historical songs on standard basics such as: "Old Turkic period." "Turko-Mongol period", "Nogaylinsky period", "Periods of the Kazakh Khanate" and others. Thus, according to the scientist, it would be possible research historical songs in organic connection with the historical events and phenomena by comparing them with the poetry of the Turkic peoples.

In this case it is necessary not to forget main properties of historical songs. "As historical song is composed very quickly, in folk poetry they are aligned with mourning songs, blessing songs, greeting songs and songs containing bad news especially death of some people. At that moment songs composed suddenly are remembered and spread differently. Only great things where the words are appropriate, particularly influencing on listener's taste and were learnt by heart unforgettable. As time goes by, they are absorbed with changes, but the main idea should remain the same." Therefore we see historical features at the heart of songs describing mourning, bad news, greeting. For example, in famous song "Karataudyn arzhagynan kosh keledi" together with expressing bad news about disaster coming to the state, it's shown how they bid farewell with Karatau lands where they were born and grew up. When it is a question of the typological study of historical songs one should be aware of their common features inherent in Turkic poetry. It should be recognized that the special works devoted purely historical typology has no songs. Nevertheless, in the works of G. Ergis [2] about Yakut folklore, Yu.I. Smirnova [15] relatively epic traditions of the Slavic peoples, N.O. Sharakshinov [14] of Buryat folklore, Russian folklorist V.Ya. Propp [12], R. Ortabayla [10] about karachayskiyi epic, from typological positions problems of the transformation, or rather rebirth of historical songs into the epic works. Of course, the extent and pace of development of the poetic heritage of different nations are various. However, the problem itself and the specific comparative studies of historical songs of different nations are important to identify in them something general and the particular. In relation to a rich Kazakh poetry, we can say, for example, in the historical songs of the Kazakhs almost the entire range of nomadic life and culture of different times are represented. "For example, in ancient and middle ages there were hero epics in folklore of the Koreans and Chinese". In all nations misfortunes and grief, sorrow and sadness of historical songs devoted mostly to the motherland, the parting with native land are revealed. E. Tursynov' $s$ researches can define concretely basis of this opinion. He says: "Considering some data, the historical songs of departing were proved to be appear based on lyrical melodies even in the period of the first social classes formation and they were composed in consequence of historical events. For example, in 121 B.C. when Chinese army headed by Huo Qubing forced huns out of hollows of Enilik mountain and Qílián mountain, it's known that huns, running off native lands, composed a song parting with their homeland. Only for lines of that historical song of parting type were stored in chroniclers' writings" [7]. Below couplets of song are given:

Enilik tauynan ayyryldyk,

Kyz-kelinshekterimiz enliksiz kaldy.

Qilian tauynan ayyryldyk, 


\section{Alty tulik malymyz kysyr kaldy [7].}

It is known that farewell songs are great values which worth of paying attention independently in general Kazakh folklore. Such songs are preserved, where the authors-poets say goodbye to family and native cities as Zhankent, Barshynkent, Syganak and Otrar, eyewitness of ancient epoch in epic "Kozy Korpesh - Bayan Sulu" "The parting with Baltaly-Baganaly" of Ayi and Tansyk

Some of the songs are called " Parting of Nogais and Kazakhs," "Weep for the death of Khan Ormanbet and unhappiness of Nogai people" and others. In this case, one drew the attention to the elegance of syllable verses, slender poetic mood and musical rhymes

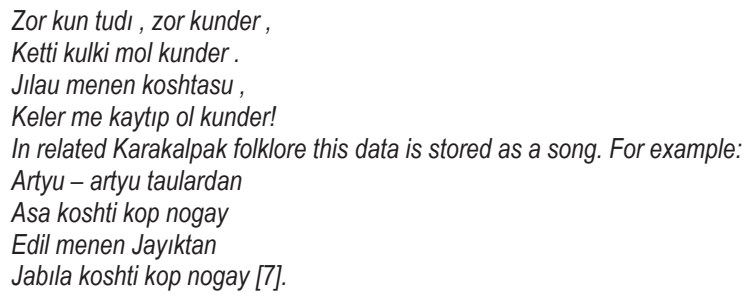

The mood of the poet is in a fine pickle. It's not easy to lose his native land and to go to other people's environment. The reason for this is a violation of the country's unity and solidarity and power of lyrical feeling is shown through grief and sorrow. Such songs, which give the early numerous historical data in Kazakh poetry, begin from Kaztugan and trace the continuity to Narmanbet and Makhambet showing historical rays of the narrow and slippery way of passed life, the incumbent clouds above the country. Many of them made the first singers be forgotten, therefore they became folk songs. The substantial evidence is known from songs such as "Farewell to Karatau", "Farewell to Saryarka", "Amanat".

The interesting problem is that the tradition of singing farewell songs, viewed in the context, is well-developed, its main feature is its similarity provided through repetition periodically and turned into general criteria (general places). There is no suffering like the loss of birthplace. Ire and wrath, sorrowful mood of people are sung by poets and zhyraus, the main indicator is that they become unforgettable remembrance in people's mind and well-known by continuous connections for centuries. They turned into common motifs:

\section{Sarezbanlı Sarı tau}

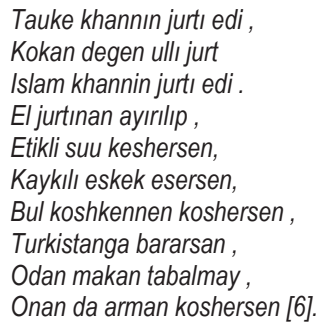

The inconsolable grief in related Karakalpak epics is reflected in the poetry of Kazakh singers - zhyraus, through the epics given below we can ascertain totally that it become the tradition at every stage. For example:

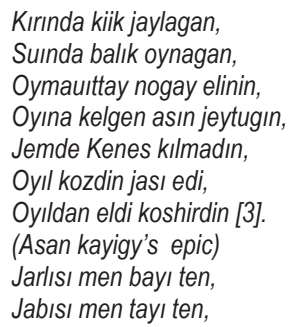




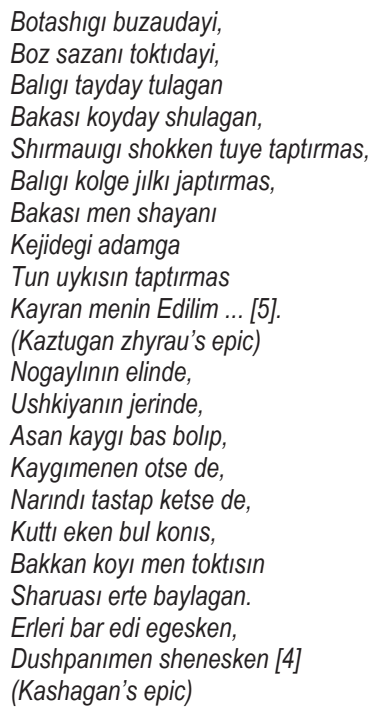

Investigation of historical poems attracted the attention of scientists, where land and water itself are the historical database of names, the chart of the space names of the historical epic was made by B.S. Rakhymov [13] , he has shown that some models of historical songs as ready cliche entered poems and realistic character of the epic has been heightened. The given above events of epics are complement of each other in terms of data, keeps track of past history. The form is similar to each other, keeping the unity of the form content, relies on its existence of forcing people to say goodbye to their motherland. Thus, historical songs are composed very fast and it's clear that the mood at that time is expressed by lyrical feeling.

We should keep in mind that akyn-zhyraus' (poets and storytellers) heritage didn't come to us as ready record, but by means of the folk tradition. It is known at the variety of social changes the folk poetry in spiritual side regenerated in accordance with the tradition and prospered.

One of the distinctive features of special tradition in folk poetry is missing and heartsinking songs. Of course, one can spread it in multiple subjects. However, it is beyond dispute that the most important among them is the left native land far away, the place of birth and childhood. The proof is classic work "Karataudyn basynan kosh keledi". Folklore scholar E.Tursynov offered as a proof the song below "Stambulga ketkenderdin oleni" expressing the signs of nostalgia for motherland:

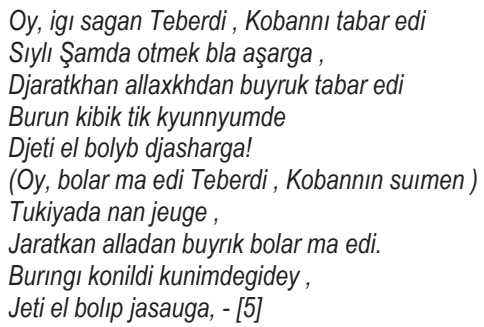

if the main city is Damascus Sham, it is known that Turkey took the power from the Arab Caliphate. They remember their own land and water than the other land. "Respect and abundance are not described but the picture is expressed only by allusion: a person, missing his native land at the outland, dreamt to eat black bread and drink water of Teberdi and Koban. On the basis of it a good image of the abundant country is made, this image with the help of lyrical strong sense is described as epical. Even if it didn't tell and picture how the lyrical hero moved to Turkey this picture appeared itself from the context of this song. "One of the signs of such nostalgia and heartsinking songs creation in earlier era is seen from the relationship of Usuns and Chinese in 105 BC. Usuns's biyi (adviser) Elzhau is given the princess of Khan king - Shizhun. But the princess Shizhun didn't know the local language. She couldn't learn their 
traditions. In such circumstances, as nostalgia for home Khan's daughter Shizhun composed "Akku ani" ("Swan Song"):

«Meni uzattı alemnin bir jagına,

Alıstagı jat elge - uysin khanına.

Dongelek uy, twirlık tam ornina

Et jep, ayran ishedi as - suina .

Tugan jerdi sagınıp, sargayamın,

Akku kus bop kaytsam dep awilima» [4].

"Khan Udi, the king of the kingdom, having heard it sent the princess presents by special ambassador during a year. Usuns's biyi Elzhau according to his original intellect decided to marry the princess Shizhun to Zhonshi biyi".

We notice that such nostalgia, longing poems in Kazakh folklore developed exclusively in the poems of the national liberation struggle especially in the XIX century and 1916.

Doskozha akyn described Kenesary khan's feeling after his leaving Sary-Arka as follows:

Bul konistan ketken son,

Izdese khalkım tabar ma

Bir kuragan shıbıgın?

Artımda kalıp barasın .

Kogerip jatkan ozenim .

Ozennin boyın bos koyıp ,

Sırtkı kogin jegenim .

Kur atına tenelgen

Jazgı mingen kobenim

Konısım kolda turganda

Bolushı edi degenim ,

At minip , jarak asıngan

Sagınar mırza oz elin [5].

Even if the poem was not sung from the mouth of Khan, akyns expressed Khan's mood, sadness and disappointment of the people. In a real historical epic "Dosan batyr (hero)" the following lines are unmistakable evidence told by his friend Isa Tlenbaev:

\footnotetext{
El kayda batır, el kayda?

Twip osken jer kayda?

Oynap - kulip bir jurgen,

Katar - kurbı ten kayda?

Shetke kettik shigandap ,

Bul juristen ne payda ? - [5]
}

lines of the poem themselves told about troubles in the region, the event of going far away from native land. They explained reasons how Dosan batyr left far away for Khoresm Bukhara having drawn in Lomakin's 700 groups. In 1916 poems of nostalgia for the native country and missing were sung in accordance with the tradition of folk poetry and revived as greeting songs. At the same time those, who were able to write letters, wrote them as a form of "Greeting letters" and many other types of poems reached the country. All poems mainly contained the appearance of a true love for native land. In this context, we see that "Dametken's sorrow", "Greeting to the country", "I also went with majority", "In saline ", "Angry revenge" and other songs reveal this topic totally, the authors of the poems were forgotten and these poems turned into the folk heritage. Connected to this upheaval fleeing to every which way and escaping to a foreign country took place. And one of the real evidences Kyrgyz akyn (poet) Iskak Shoibekov described the situation of people who fled to China and revealed specially in his creation "Kairan el". For example:

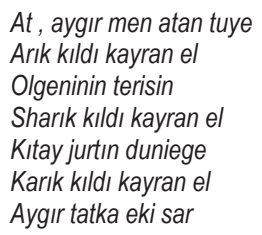




\author{
Narık kıldı kayran el \\ Jirgap jatkan jandarın \\ Garıp kıldı kayran el \\ Bir juz somdık Ak narın \\ Sarge sattı kayran el, \\ Algan jerin bir kongan \\ Tekke sattı kayran el . \\ Ala kiiz tosek jok, \\ Jerge jattı kayran el [3].
}

The fate of the country, the condition of the population without former abundance forced the poet to sing with indignation.These poems we can meet in Kazakh folk songs of such poets as Buzaubak, Narmanbet, Toleu, Boltirik, Isa, Zhambyl. We totally see that the theme of the song and even the internal similarity between the era and tradition continue constantly. Such typological compliance can be noticed in the poems of mourning and praise. One can give numerous examples of continuous development and prosperity of mourning poems sung for famous batyrs (heroes), khans and biyis and prosperity seat in early times. After analysis we noticed such regularities in the related Kyrgyz, Karakalpak, Tajik, Bashkir folklore.

Farewell, funeral, mourning, greeting, nostalgia and longing, praising songs being noticed from the nature of historical poems gradually took epical features during the development and as a result typological studies proved the appearance of extensive historical epics. From thematic point historical songs inform about significant events of different history of countries, having absorbed features of the early century. It is not so difficult to recognize hard time in 1996, "XX century's upheaval", "Aktaban shubyryndy, Alka kol sulama". Therefore, professor N.S. Smirnov says: "Essential features of historical songs corresponding to only original creations are kept in the smallest types". It is known that the very proof is famous historical songs for us. We decided to research the substantiation of this conclusion from historical songs composed according to the national liberation revolution in 1916. The fact that the national liberation revolution in 1996 became the period of great difficulties for Kazakh people and it is highly estimated in historical works. "Lands of working Kazakhs particularly were taken away mostly and divided to civil servants, officers of czar and Kazakh horse guards. Only in Zhetysu region in 1913-1915 1800 tithes of land were taken to divide, among them in Verniyi (Almaty) city the chief of police Protikov was given 10000 tithes of land". "The reign took up with force from local people lands with barns and cowsheds, built houses, planted trees with utilized water supply". "Hence the fund of changing residence was established. And before the revolution in 1996 the size of tithe taken from Kazakh lands increased to 20 million". In one should also add the order made by Nikolaiy czar about taking people for spade work of front line among indigenous population of Middle Asia in June, 25 in 1916. It was the main reason to kindle power and strength, revenge and anger of people who had numerous subtractions of protecting their rights. Rebels and strikes were seen everywhere, and consequently they continued into the general national movement. The picture of these historical situations took special place in historical songs. Poets-improvisators totally covered and put on scale the truth of the century. Numerous difficulties of life and hours of trial left an imprint on the national poetry. "Such epoch in age-old genealogy was "June order" which bound with collar, encouraged children of one generation to hostility, bruised the blade of the sword having been taken from the scabbard in consequence of dishonesty, nevertheless that turmoil in 1916 was significant due to the descendants who could protect their treaded down honour, who was ready to devote their life to escalate the light of good hope into great national invasion". From that time a lot of generation changed, many Kazakh young people grew up. But our nation never forgets the czar's order to make everlasting slaves from Kazakh young people between the age of 19 and 31 for spade work in that period. One of the features is epical songs which brought us melodies of vast steppes and grief of widows and orphans; they are very valuable by their memory showing us circumstances of hard time. For example:

\footnotetext{
Jaz kuni, uyel ayı on besinde,

Kuni ashık jarkıragan dal besinde

"On togız ben otız birdi » alad degen

Shoshıgan suık khabar ali esimde.

Suradık agayın bop bolısınan ,

Soz tartıp kasındagı orısınan

«Bir ayla kaluga aman sebep bolar»,

Dep oylap kop khalıktın jorasınan

Bolıs ta on bermedi tusi suık,

Manınan bargan jandı jatır kuıp .
} 


\section{Ak uyden shıgip jatır konili suip . \\ Bulindi eldin ishi - ulau - shulau, \\ Bul istin tubi ne?, - dep boldı jllau . \\ Beldeude bir - bir attı baylap koydık, \\ Akırı ne bolar dep , yapırm - au [6].}

Yes, it was only one moment of hard time for our people. Poets - improvisators Battal, Zhambul, Omar Shipin, Kuderi, Akmolda, Isa, Darkembayuly, Narmambet, Sat, Toleu, Eskayiyr, Boltirik and many other poets tried to delate us sorrow and anger of people. Basically, historical poems related to the events in 1916 were sung in the form of mourning, farewell, greetings and they specify in expressing the truth of the era impressively. The following song of farewell is like proof of our opinion. An example is:

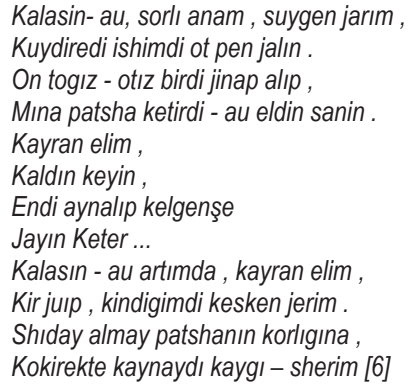

If we say that it is one of the poems spread as song among people of that time, we notice that such farewell songs devoted to the people are phenomena corresponding to poetry of that century. Scientists relevantly mention creations of poets-improvisators such as "Saryarkamen koshtasu" (Farewell with Saryarka), "El zhurtymen koshtasu" (Farewell with their native heath), "Auldan attanganda" (When one left place of birth).

The meanings of these songs are always serious from the position of imaging the truth of historical life. Songs, describing circumstances of historical epoch mentioned above, are different. In this connection, firstly work of selecting, thinking of songs related to the upheaval should be on the 1 ${ }^{\text {st }}$ place. Secondly, poems related to 1916 and connected to the development of historical events are seen in different genres. In addition, the forms of songs absorbed mostly the nature of simple songs (connected to Kazakh folk art). In this connection, M. Zharmukhamedov conducted researches connected to theme of that period and his opinion is appropriate: "So, poetry of strike in 1916 was born and developed on the traditional basis of an ancient folklore. Therefore these epics from the descriptive and art, typical and form methods, have been keeping ordinary examples of folklore totally. Nevertheless the struggle poetry of 1916 had its own many peculiarities and new features and the problem should be paid special attention to" [20]. Referring to the truth, even educated and intelligent people participated in the struggle for national independence in 1916. But greeting and farewell poems spread quickly among people and as the time passed names of authors were forgotten. We defined it from the leaders Amangeldy and Bekbolat's dedication for people, they saw those events and took part in those strikes. And the main heroes of historical songs devoted to the strike of 1916 were Amangeldy and Bekbolat, people were satisfied with them, they were considered to be the support for people. Then little poems extended and turned into large epical folk tales.

\section{Results}

So, making a conclusion it is right to consider poems related to the national liberation uprising in 1916 as a visible bright part from the quality point, rich in poetic features of the new spirit of our people and recognize the historical traces in the poetry. We noticed that especially the poems of 1916 were investigated more among the problems of historical songs and the representatives of scientific society were interested in them. From this point works of E.Ysmailova [11], B.Kenzhebayev [9], M. Zharmukhamedov [20] never lose their value.

All mentioned scientists said the historical character of folk art connected with the events in 1916 was rich and emphasized that lyrical features of poems were predominate in that period. The same opinion was said by B. Uakhatatov who researched carefully historical songs after the above-mentioned scientists. He said: "Indeed, the size of small types of historical songs is short, they are like sketches, they seem to show separately moments revealing ideas of songs 
describing particular events. And they are given in lyrical plan having decorated impressive feelings and flexible language. Here, taking from this direction small types of historical epics are considered as some branches of lyrical songs" [18]. All poems in national poetry are combined with lyrics. If one needs, amazing examples of lyrics meet in historical epics, amorousness and courage songs, epics of customs and traditions. Original nature of lyrical songs is very tender, romantic, with sad tunes, love and wonderful effects of nature. The historical songs, we are talking about, have predominately grief and anxiety, in addition it is clear that they represent exactly the real historical event. If it is so, these songs can be concluded as pure lyrical creature. A lot of farewell and will songs occur even in very ancient examples of historical songs. There is enough proof for songs composed according to events of XVIII-XIX centuries. Considering the problem attentively we see that a historical event itself is appeared to be the important peculiarity revealing the main idea of a song. To this point of view the substantiation of Bulgarian scientist Z. Borodov's opinion given below: "Constant signs of genres are changing according to every epoch and receive much additional features. But those features are not defined as very significant, therefore it doesn't have any affect in analyzing some work in one particular genre. In this reason in any historical moment some creation can be considered in different genres. In such situations the thing playing the main role is the most important feature in the structure (nature) of the work. For example in antique period "Odyssey" was referred to epopee genre, nowadays it is considered as "epic" genre or "mythological epic". (Taken from "Kazakh folk prose" according to S.Kaskabasov's translation). Taking from this point the main feature of historical songs and actual problem are historical event, taking into account the event that happened or is happening now the backbone of historical songs being considered either epic poetry or lyrics is historicity. Traditional examples of songs in poetry related to the customs and traditions have relations to all types, being formed in a new insight, promoting their development and basis of historical song is features and secrets of action in real.

Therefore it is necessary to balance a historical song by measuring actions being revived by epoch and paying attention to sorrows, anger, dreams and wishes of people in difficult period of time. In every nation the history of great caravan called "life" in time space is well-known by different troublesome times and periods. For Kazakh people folk poetry is similar to the history of past life. "Folk songs are the truth mirror of Kazakh life, one of the types of folklore originated from customs and traditions, labours and everyday life having been established through centuries". Having interested in folk poetry and tried to make a classification for genre types Shokan Valikhanov said: "Due to consciousness of akyns - improvisators all ancient epics according to their old language, the occurrence of many strange words for new generation, historical facts about heroes, many of them were created in the age of Altyn Orda and came to us in pure and original type" [17]. It's wonderful and that ancient legends and true stories kept in pure state and the most amazing phenomena the examples especially epical creations are sung similarly both outskirts and vast steppes, when comparing them there is no difference between first and second variants. That it is amazing it is doubtless fact". From this point of view it is true what's said about general folk poetry and epical folk tales. If we rely on this opinion, no doubt that the structure and feature of historical songs in folk poetry ate totally separated. It's obvious historical sings occur in folklore of all countries. But from historical point different peculiarities of songs can definitely be noticed. For example, in western folklore historical songs have features of fighting, sorrows and impacts of wars, in eastern countries because of tumult severe aggression, disaster and tragedy the fate of peoples losing their lands and searching for retreat was reflected in songs.

Only historical songs can show the formation of Kazakh state as separate country and the struggle for independence have been continuing through centuries. History has been defining difficult times and black clouds over the head of Kazakh people from XV century, the formation of khanate.

Referring to history the number of different strikes, severe destructions, sudden invasions, the threat over the country is more 300. It is easy to say, but it is the truth and regret of the past time. They are historical songs that penetrated those images and facts of epochs and periods into the substance of general people's psychology.

When the nation lost its abundance, had different disasters, sorrows of people were the main support in creatures of representatives in improvisation art. In general they turned into sad songs.

Thus, historical songs are real mirrors of events and in any time and period they are rebounding.

\section{Discussion}

Analyzing from different perspectives the origin and development of historical songs in Kazakh folklore, comparing with historical songs of other peoples, searching for the first time poetic peculiarities and defining the genre feature are the originality of the theme. The significant scientific novelties of the research:

- Original conclusions related to completion and thematic grouping of historical songs were offered;

- Interconnection of historical songs with other genres of folklore, giving answers for various points of view 
concerned differences between historical songs and epics and new scientific concepts about influence of historical songs and epics were made;

- The relation between historical songs and creatures of akyns-improvisators were represented;

- The main novelty of the article is an interpretation of historical songs from unified poetic and typological point.

\section{Conclusion}

- New conclusions on questions of classification and integrity of historical songs are made;

- Answers to the various questions, historical songs concerning interrelation with other genres of oral national creativity and distinctions between historical songs and historical jir are given, the scientific concept about influence of historical songs on historical jirs is made;

- The interrelation of historical songs with improvisatory creativity akyns and their folklore basis is determined;

The basic novelty of dissertational work is research of artistry of a word and language in historical songs from a position of poetic aspect.

\section{References}

Auezov M. (1962). Time and literature. Almaty.

Ergis G.U. (1974). Essays on the Yakut folklore. Moscow.

Fund of CSL (Fund of the Central Scientific Library). 1077 package.

Fund of CSL. 833 package. 10 copybooks.

Fund of CSL. 954 package.

Fund of CSL. 25 package. 1 copybooks. Issues of Kazakh historical songs. (1979). Almaty: Gylym Kaskabasov S. (1984). Kazakh national prose. Almaty.

Kenzhebaev B. (1956). Songs of the 1916 uprising. Almaty.

Ortabaylany R. (1969). Қarachay halkny dzhyrlaryny yusyunden. -Kitap. "Қarachay halқ dzhyrla." Moscow.

Putilov B.N. (1960). Russian historical and song folklore of XIII-XIX centuries. M-L.

Propp V.Ya. (1964). -№ 4. Genres of Russian folklore. Russian literature.

Rakhymov B.S. (1999). Nature of historical epic. Karagandy: KarSU Publishing House.

Sharakshinova N.O. (1959). Buryat folklore. Irkutsk.

Smirnova Yu.I. (1974). Slavic epic tradition. Problems of evolution. Moscow.

Stebleva I.V. (1965). Poetry of Turks in VI - VII centuries. Moscow.

Uakhatov B. (1974). Kazakh folk songs. Almaty: Gylym

Valikhanov Ch. Ch. (1961). Collected works. - V.I. Alma-Ata

Ybyraev Sh. (1991). Kazakh folkloristics: yesterday, today, tomorrow. Alem Almanac. Almaty.

Zharmukhametov M. (1962). Revolt of 1916 in Kazakh folk poetry. Abstract for the degree of the candidate of philological sciences. Alma-Ata. 